\title{
ENTREPRENEURIAL FACTORS INFLUENCING BUSINESS SUCCESS IN MICRO, SMALL AND MEDIUM ENTERPRISES IN MUARADUA SUBDISTRICT SOUTH OKU REGENCY
}

\author{
Angga Wibowo Gultom *) \\ Dyah Ayu Putriani **) \\ Baturja University
}

\begin{abstract}
Analyzer used in this research is multiple linear regression. This study discusses the influence of the business environment, the availability of capital and marketing strategies that influence the success of Micro, Small and Medium Enterprises (UMKM) in Muaradua subdistrict South OKU Regency either simultaneously or partially. The results of this study were found positive and significant influence both partially and simultaneously between the Business Environment (X1), availability of capital (X2) and Strategic Marketing (X3) influence the entrepreneurial success (Y). $\mathrm{R}^{2}$ value (Adjusted R Square) of 0.920 or (92\%). This shows that the Business Environment (X1), Capital Availability (X2) and Strategic Marketing (X3) influence the entrepreneurial success (Y) while the remaining $8 \%$ are influenced or explained by other variables not included in the model of this study is the participation of members, cooperative management, cooperative management and cooperative financial report (Hanafiah, 2012).
\end{abstract}

Keywords: business environment, availability of capital, marketing strategy

\begin{abstract}
Abstrak
Alat analisis yang digunakan dalam penelitian ini adalah regresi linier berganda. Penelitian ini membahas tentang pengaruh lingkungan usaha, ketersediaan modal dan strategi pemasaran yang mempengaruhi keberhasilan Usaha Mikro Kecil dan Menengah (UMKM) di Kecamatan Muaradua Kabupaten OKU Selatan baik secara simultan maupun parsial. Hasil penelitian ini adalah terdapat pengaruh yang positif dan signifikan baik secara parsial dan simultan antara Lingkungan Usaha $\left(X_{I}\right)$, Ketersediaan Modal $\left(X_{2}\right)$ dan Strategi Pemasaran $\left(X_{3}\right)$ berpengaruh terhadap Keberhasilan Wirausaha (Y). Nilai $R^{2}$ (Adjusted $R$ Square) sebesar 0,920 atau (92\%). Hal ini menunjukkan bahwa Lingkungan Usaha $\left(X_{1}\right)$, Ketersediaan Modal $\left(X_{2}\right)$ dan Strategi Pemasaran $\left(X_{3}\right)$ berpengaruh terhadap Keberhasilan Wirausaha (Y) sedangkan sisanya sebesar 8\% dipengaruhi atau dijelaskan oleh variabel lain yang tidak dimasukkan dalam model penelitian ini yaitu partisipasi anggota, pengurus koperasi, manajemen koperasi, dan laporan keuangan koperasi (Hanafiah, 2012).
\end{abstract}

Kata Kunci: lingkungan usaha, ketersediaan modal, strategi pemasaran 


\section{INTRODUCTION}

The government pays great attention to the development of Micro, Small and Medium Enterprises (UMKM). Not only do the number of MSMEs in Indonesia dominate, but also MSMEs can survive the global crisis more. Various initiatives have been attempted by the government through the government through the State Ministry for Cooperatives and Small and Medium Enterprises so that more individuals want to pursue the world of entrepreneurship in the form of establishing MSMEs (Purwanti, 2012: 13).

Independent entrepreneurship is needed by individuals who are ready to fight entrepreneurship because their efforts are sensitive to a sharp conscience and business instinct to penetrate a competitive market share (Bawsir in Purwanti, 2012: 14). Entrepreneurial characteristics can influence the development of their business, entrepreneurial characteristics the need for success, the desire to take risks, selfconfidence and a strong desire to do business, in addition to the entrepreneurial characteristics of venture capital is absolutely necessary in conducting business activities. Entrepreneurs generally have the same characteristics, they are people who have energy, a desire to be innovative, a willingness to accept personal responsibility for realizing an event in the way they choose, and a desire for very high achievement, an optimistic attitude and trust in the future. Although the rewards for entrepreneurship are lucrative, there are also costs associated with owning the business. Starting and operating his own business, it is hard work, takes a lot of time and requires emotional strength. Entrepreneurs experience unpleasant personal pressures such as the need to invest more time and energy. Many entrepreneurs describe their career as fun, but very consuming everything (Masykur, 2001: 14).

The number of Micro, Small and Medium Enterprises (MSMEs) in Muaradua subdistrict, South OKU Regency which researchers obtained at the Office of Cooperatives, SMEs, Industry, Markets and Trade of Ogan Komering Ulu Selatan Regency is 70 MSMEs, among which are engaged in milling coffee, rice, making tempe and tofu, as well as making crackers. These Micro, Small and Medium Enterprises (MSMEs) are fostered businesses of the Department of Industry, Trade, Cooperatives and SMEs, where once a year they are given training by the agency as an effort to improve the knowledge and skills possessed by the UMKM.

The business environment is one of the factors that greatly determines the success of a business in the era of free trade. Based on the results of observations made by researchers, the average environment where the establishment of Micro, Small and Medium Enterprises (MSMEs) seems less strategic, where the MSMEs are rather remote from residential areas so that it is difficult for them to distribute their products. So it is not uncommon for the quality of the product to decline and be damaged, as a result, the level of losses experienced is increasing day by day.

The capital availability factor also greatly influences the growth and development of Micro, Small and Medium Enterprises (MSMEs) in Muaradua subdistrict, South OKU Regency. Based on the results of interviews with researchers with several owners of Micro, Small and Medium Enterprises (UMKM) in Muaradua subdistrict, South OKU Regency, currently they are experiencing capital difficulties, both for production costs and operational costs. This is because there is no partnership system / foster figure in Ogan Komering Ulu Regency, so that not a few of the existing MSMEs are out of business due to bankruptcy.

Apart from the social environment and the availability of capital, marketing strategies are also one of the factors that influence the success of a Micro, Small and Medium Enterprise (UMKM). Based on the results of preliminary observations made by researchers here, it can be seen that the marketing strategies carried out by Micro, Small and Medium Enterprises (MSMEs) in Muaradua District, South OKU Regency, are considered not optimal. Where the market selection they have is still very minimal because employees who have been trained in their fields, after having sufficient knowledge and experience, they stop to open their own businesses, so that existing employees are only new employees 
who do not have work experience. In addition, some employees are also unable to communicate (promotion) properly, so that they do not attract the attention of consumers.

\section{LITERATURE REVIEW}

\section{Company Environment}

The business environment is anything that influences business activities in an organization or company. The business environment cannot be ignored. The business environment can be both a driving force and a hindrance to the company's running. The environment that can influence the running of a business / company is the micro environment and the macro environment (Suryana in Setiaji, 2009: 24).

According to Setiaji (2009: 24), the micro environment is an environment related to company operations, such as suppliers, employees, shareholders, employers, managers, directors, distributors, consumers and others. If this is in line with the shift in marketing strategies, namely from corporate profit gainers (shareholders) to benefits for stakeholders, the internal environment, both individuals and groups who have an interest in the company, will be very influential. The macro environment is an environment outside the company that can influence the overall life force of the company, which includes the economic environment, the technological environment, the sociopolitical environment, the demographic environment and the lifestyle.

\section{Capital Availability}

According to Purwanti (2012: 18), in running a business, one of the supporting factors needed is capital, if we are like starting a business by building a house, then the capital becomes part of the foundation of the house to be built. The stronger the foundation that is made, the stronger the house is built. Likewise, the influence of capital on a business, its existence becomes the initial foundation for the business to be built. Some of the capital needed to run a business, including determination, experience, courage, knowledge, net working, and financial capital, however, most people are hampered from starting a business because they find it difficult to get financial capital.

Bambang (2001: 18) states that venture capital is absolutely necessary to carry out business activities. Therefore a number of funds are needed as a basis for financial measurement of the efforts being encouraged. Sources of business capital can be obtained from own capital, government assistance, financial institutions both banks and non-bank financial institutions. Capital is a business factor that must be available before carrying out activities. The size of the capital will influence the development of business in achieving income, another meaning of capital includes both capital in the form of money and in the form of goods.

\section{Marketing Strategy}

Marketing is one of the main activities carried out by entrepreneurs in their efforts to maintain the survival of the company and its business development and earn a profit. Success or failure in achieving goals depends on the ability and expertise in marketing.

In achieving the goal, it is necessary to have a marketing strategy, namely a plan that is owned by a company as a guide for marketing activities in order to achieve the goals set by the company (Basu Swasta \& Irawan, 1990: 19). In starting a business, it is necessary to have a preliminary marketing strategy plan to introduce the new product to the market. The plan consists of the first three parts of product positioning, market share. The second part is about distribution strategy and budget. The third 
part is to implement a marketing mix strategy, namely a strategy on price, distribution, products, promotions that will be carried out.

Marketing strategy is a statement (either implicitly or explicitly) about how a brand or product line achieves its goals Bennett in Tjiptono (2008: 19). Meanwhile, Tull and Kahle in Tjiptono (2008: 19) define marketing strategy as a fundamental tool that is planned to achieve company goals by developing sustainable competitive advantage through the entered market and marketing programs used to serve these target markets. Basically, the marketing strategy provides direction in relation to variables such as market segmentation, target market identification, positioning of marketing mix elements, and marketing mix costs.

\section{Research Conceptual Framework and Hypothesis}

Every company, in this case an MSMEs, is certain to want the progress of the MSMEs. The progress of MSMEs can be influenced by several variables, namely: (business environment, availability of capital and marketing strategies). In the framework variable, there are arrows that show the influence of the independent variables on the dependent variable. The theoretical framework is presented as follows:

Figure 1

Research Conceptual Framework

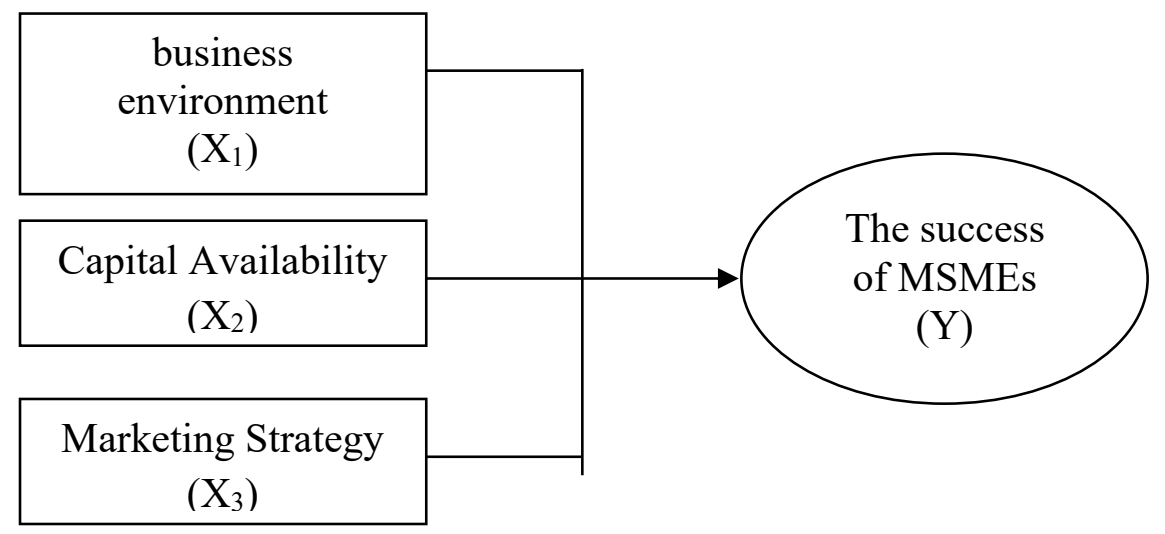

\section{RESEARCH METODS}

This research was conducted at Micro, Small and Medium Enterprises (UMKM) in Muaradua subdistrict, South OKU Regency. The variables studied were: the influence of the business environment, availability of capital and marketing strategies that influenced the success of Micro, Small and Medium Enterprises (MSMEs) in Muaradua subdistrict, South OKU Regency. This study uses primary data.The characteristics of the respondents in this study included gender, age, and education with a total of 70 respondents. Respondents in this study were all owners of Micro, Small and Medium Enterprises (MSMEs) in Muaradua, South OKU Regency.

\section{RESULT ANALYSIS AND DISCUSSION}

The validity test is a test measuring tool in the questionnaire. The validity test is used to measure the accuracy of an item in the questionnaire or scale, whether the items on the questionnaire are correct in 
measuring what you want to measure, or you can do a direct assessment using the Pearson correlation method or the corrected item-total correlation method.

Table 1

Validity Test Results

\begin{tabular}{|c|c|c|c|}
\hline \multicolumn{4}{|c|}{ Business Environment $\left(\mathrm{X}_{1}\right)$} \\
\hline Statement Items & r-count & r-table & information \\
\hline P1 & 0,539 & 0.2387 & Valid \\
\hline $\mathrm{P} 2$ & 0,694 & 0.2387 & Valid \\
\hline P3 & 0,688 & 0.2387 & Valid \\
\hline P4 & 0,701 & 0.2387 & Valid \\
\hline \multicolumn{4}{|c|}{ Capital availability $\left(\mathbf{X}_{2}\right)$} \\
\hline P1 & 0,468 & 0.2387 & Valid \\
\hline $\mathrm{P} 2$ & 0,493 & 0.2387 & Valid \\
\hline P3 & 0,724 & 0.2387 & Valid \\
\hline P4 & 0,573 & 0.2387 & Valid \\
\hline P5 & 0,634 & 0.2387 & Valid \\
\hline P6 & 0,631 & 0.2387 & Valid \\
\hline \multicolumn{4}{|c|}{ Marketing Strategy $\left(\mathbf{X}_{3}\right)$} \\
\hline $\mathrm{P} 1$ & 0,528 & 0.2387 & Valid \\
\hline $\mathrm{P} 2$ & 0,588 & 0.2387 & Valid \\
\hline P3 & 0,503 & 0.2387 & Valid \\
\hline P4 & 0,649 & 0.2387 & Valid \\
\hline $\mathrm{P} 5$ & 0,582 & 0.2387 & Valid \\
\hline P6 & 0,655 & 0.2387 & Valid \\
\hline P7 & 0,627 & 0.2387 & Valid \\
\hline P8 & 0,450 & 0.2387 & Valid \\
\hline P9 & 0,482 & 0.2387 & Valid \\
\hline P10 & 0,433 & 0.2387 & Valid \\
\hline \multicolumn{4}{|c|}{ Entrepreneurial Success (Y) } \\
\hline P1 & 0,584 & 0.2387 & Valid \\
\hline $\mathrm{P} 2$ & 0,584 & 0.2387 & Valid \\
\hline
\end{tabular}




\begin{tabular}{|l|c|c|c|}
\hline P3 & 0,687 & 0.2387 & Valid \\
\hline P4 & 0,713 & 0.2387 & Valid \\
\hline P5 & 0,752 & 0.2387 & Valid \\
\hline P6 & 0,475 & 0.2387 & Valid \\
\hline
\end{tabular}

Source: processed Primary data, 2015

Based on the results of the validity test of 70 respondents, it is known that the value (corrected item total correction) $r$-count for each item of statement from the independent variable is greater than the $r$-table so it can be concluded that each item of statement used is valid.

Table 2

Reliability Test Results

\begin{tabular}{|l|c|l|}
\hline \multicolumn{1}{|c|}{ Variables } & Coefficient of Alpha & Information \\
\hline Business Environment $\left(\mathrm{X}_{1}\right)$ & 0,826 & Reliable (Good) \\
Capital availability $\left(\mathrm{X}_{2}\right)$ & 0,821 & Reliable (Good) \\
Marketing Strategy $\left(\mathrm{X}_{3}\right)$ & 0,847 & Reliable (Good) \\
Entrepreneurial Success (Y) & 0,838 & Reliable (Good) \\
\hline
\end{tabular}

Source: processed Primary data, 2015

Based on the table above it can be seen that the Cronbach's Alpha value for the Business Environment variable (X1) is 0.826 , Capital Availability (X2) is 0.821 , the Marketing Strategy variable (X3) is 0.847 and the Entrepreneurial Success variable $(\mathrm{Y})$ is 0.838 . This means that all the questions from all variables can be said to be reliable or suitable for use as a research tool.

Table 3

Multicollinearity Test Results

\begin{tabular}{|l|c|c|}
\hline \multicolumn{1}{|c|}{ Independent Variables } & Tolerance & VIF \\
\hline Business Environment $\left(\mathrm{X}_{1}\right)$ & 0,200 & 5,008 \\
Capital availability $\left(\mathrm{X}_{2}\right)$ & 0,548 & 1,825 \\
Marketing Strategy $\left(\mathrm{X}_{3}\right)$ & 0,150 & 6,688 \\
& & \\
\hline
\end{tabular}

Source: processed Primary data, 2015

In the Coefficients table (a) above, the VIF of each variable, namely the value of the Business Environment variable (X1) is 5.008 with a tolerance value of 0.200 , while the Capital Availability (X2) variable is 1.825 with a tolerance value of 0.548 , and the Marketing Strategy variable ( X3) of 6.688 with a tolerance value of 0.150 . This shows that the two $X$ variables have a VIF value $<20$ and a tolerance value $>0.05$. This means that there are no symptoms of multicollinearity.

Picture 1 


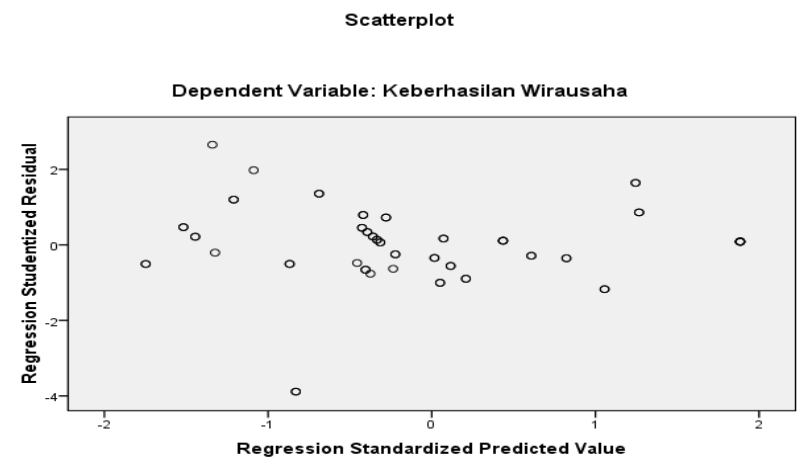

Picture 1 shows that the distribution of the residuals is irregular. The dots spread below and over the $\mathrm{Y}$ axis, and do not have a regular pattern. So in conclusion, the independent variable does not occur heteroscedasticity or is homoscedasticity

Picture 2

Normal P-P Plot of Regression Standardized Residual

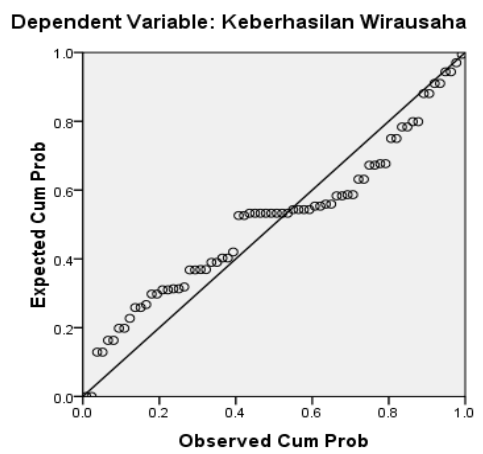

In Picture 2 the graph shows the P-P plot located around the diagonal line. The plot does not deviate far from the diagonal line, so it can be interpreted that the distribution of data on Business Environment (X1), Availability of Capital (X2) and Marketing Strategy (X3) is normal.

Table 4

Model Summary ${ }^{\text {b }}$

\begin{tabular}{|c|c|c|c|c|c|}
\hline Model & $\mathrm{R}$ & R Square & $\begin{array}{c}\text { Adjusted R } \\
\text { Square }\end{array}$ & Std. Error of the Estimate & Durbin-Watson \\
\hline 1 & $.961^{\mathrm{a}}$ & .924 & .920 & 2,12813 & 1.448 \\
\hline
\end{tabular}

Source: processed Primary data, 2015

In table 4 it can be seen that the DW value generated from the regression model is 1.448 and is located between -2 to +2 , so this research data does not occur autocorrelation.

Table 5

Results of Multiple Linear Regression Analysis 


\begin{tabular}{|c|c|c|c|c|c|c|c|}
\hline \multirow[b]{2}{*}{ Model } & \multicolumn{2}{|c|}{$\begin{array}{l}\text { Unstandardized } \\
\text { Coefficients }\end{array}$} & \multirow{2}{*}{$\begin{array}{l}\text { Standardized } \\
\text { Coefficients } \\
\text { Beta }\end{array}$} & \multirow[b]{2}{*}{$\mathrm{t}$} & \multirow[b]{2}{*}{ Sig. } & \multicolumn{2}{|c|}{$\begin{array}{l}\text { Collinearity } \\
\text { Statistics }\end{array}$} \\
\hline & B & Std. Error & & & & Tolerance & VIF \\
\hline (Constant) & 10.247 & 1.206 & & 8.495 & .000 & & \\
\hline Business & .378 & .054 & .532 & 7.008 & .000 & .200 & 5.008 \\
\hline मान & & & & & & & \\
\hline $\begin{array}{l}\text { Capital } \\
\text { availability }\end{array}$ & .195 & .076 & .118 & 2.573 & .012 & .548 & 1.825 \\
\hline Marketing & & & & & & & \\
\hline Strategy & .247 & .056 & .390 & 4.442 & .000 & .150 & 6.688 \\
\hline
\end{tabular}

Source: processed Primary data, 2015

Based on the results of the calculation of multiple linear regression analysis with the help of the SPSS 16 program, multiple linear regression equations can be compiled as follows:

$$
\mathrm{Y}=\mathbf{1 0 . 2 4 7}+\mathbf{0 . 3 7 8} \mathrm{X} 1+\mathbf{0 . 1 9 5} \mathrm{X} 2+\mathbf{0 . 2 4 7} \mathrm{X3}+\mathrm{e}
$$

Where: $\mathrm{Y}=$ dependent variable (entrepreneurial success)

$\mathrm{X}_{1}=$ independent variable (Business Environment)

$\mathrm{X}_{2}=$ independent variable (Availability of capital)

$\mathrm{X}_{3}=$ independent variable (Marketing Strategy)

$\mathrm{e}=$ error term

The above equation can be interpreted as follows:

1. A constant value of 10,247 states that if there are no Business Environment (X1), Capital Availability (X2) and Marketing Strategy (X3) variables, then Entrepreneurial Success (Y) is a constant of 10,247.

2. Business Environment regression coefficient (X1) of 0.378 states that for each addition of one unit of Business Environment (X1), Entrepreneurial Success (Y) also increases by 0.378 provided that Capital Availability (X2) and Marketing Strategy (X3) are fixed.

3. The regression coefficient value of Capital Availability (X2) is 0.195 which states that for each addition of one unit of Capital Availability (X2), Entrepreneurial Success (Y) also increases by 0.195 provided that the Business Environment (X1) and Marketing Strategy (X3) are fixed.

The marketing strategy regression coefficient (X3) of 0.247 states that for each addition of one unit of Marketing Strategy (X3), Entrepreneurial Success (Y) also increases by 0.247 provided that the Business Environment (X1) and Business Environment (X2) are fixed and constant.

Table 6

T-test results

\begin{tabular}{|l|c|c|c|c|}
\hline Independent Variables & t-Count & t-table & Sig & Information \\
\hline $\begin{array}{l}\text { Business Environment } \\
\left(\mathrm{X}_{1}\right)\end{array}$ & 7,008 & 1.99714 & 0,000 & Significant \\
\hline Capital Availability $\left(\mathrm{X}_{2}\right)$ & 2,573 & 1.99714 & 0,000 & Significant \\
\hline Marketing Strategy $\left(\mathrm{X}_{3}\right)$ & 4,442 & 1.99714 & 0,000 & Significant \\
\hline
\end{tabular}

Source: processed Primary data, 2015

Based on the results of data processing contained in table 6 , it is obtained: 
1. The coefficient t count for Business Environment (X1) is 7.008 and the $t$ table value is 1.99714. So it can be concluded that $t$ count $>t$ table is 7.008 greater than 1.99714, so Ho is rejected, which means that the Business Environment (X1) has a significant influence on Entrepreneurial Success (Y).

2. The t coefficient of capital availability (X2) is 2.573 and the $t$ table value is 1.99714 . So it can be concluded that $\mathrm{t}$ count $>\mathrm{t}$ table is 2.573 greater than 1.99714, so Ho is rejected, meaning that the Availability of Capital (X2) has a significant influence on Entrepreneurial Success (Y).

3. The coefficient $t$ count for the Marketing Strategy (X3) is 4.442 and the $t$ table value is 1.99714 . So it can be concluded that $\mathrm{t}$ count $>\mathrm{t}$ table is 4.442 greater than 1.99714, so Ho is rejected, meaning that Marketing Strategy (X3) has a significant influence on Entrepreneurial Success (Y).

This can be illustrated in Picture 3 below:

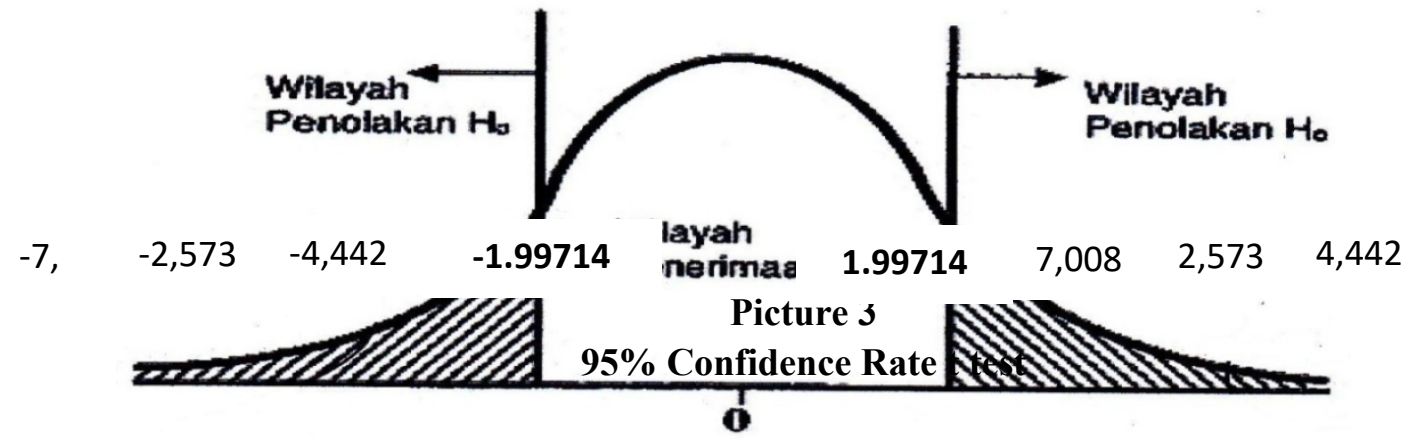

Table 7

Altogether Test Results

\begin{tabular}{|c|c|c|c|c|}
\hline Independent Variables & F-Count & F-table & Sig. & Information \\
\hline $\begin{array}{l}\text { Business Environment }\left(\mathrm{X}_{1}\right) \\
\text { Availability of Capital }\left(\mathrm{X}_{2}\right) \\
\text { Marketing Strategy }\left(\mathrm{X}_{3}\right)\end{array}$ & 267,122 & 2.74 & 0,000 & Significant \\
\hline
\end{tabular}

Source: processed Primary data, 2015

Based on table 7, the results of data processing obtained a coefficient of F-count value of 267,122 which is greater than the F-table value of 2.74, this means that Fcount> Ftable, so Ho is rejected, Ha is accepted, meaning Business Environment (X1), Availability of Capital (X2) and Marketing Strategy ( X3) influences Entrepreneurial Success (Y).

Table 8

Model Summary ${ }^{b}$

\begin{tabular}{|l|r|r|r|r|r|}
\hline Model & \multicolumn{1}{|c|}{$\mathrm{R}$} & R Square & $\begin{array}{c}\text { Adjusted R } \\
\text { Square }\end{array}$ & Std. Error of the Estimate & Durbin-Watson \\
\hline 1 & $.961^{\mathrm{a}}$ & .924 & .920 & 2,12813 & 1.448 \\
\hline
\end{tabular}

Source: processed Primary data, 2015 
Based on table 8 , the $\mathrm{R}^{2}$ (Adjusted $\mathrm{R}$ Square) figure is 0.920 or $(92 \%)$. This shows that the Business Environment (X1), Availability of Capital (X2) and Marketing Strategy (X3) have an influence on Entrepreneurial Success (Y) while the remaining $8 \%$ is influenced or explained by other variables not included in this research model, namely member participation, cooperative management, cooperative management, and cooperative financial reports (Hanafiah, 2012).

\section{CONCLUSION}

Based on the analysis and discussion that has been carried out, the following conclusions can be drawn:

1. There is a positive and significant influence both partially and simultaneously between the Business Environment (X1), Availability of Capital (X2) and Marketing Strategy (X3) to influence Entrepreneurial Success (Y).

2. Value of $\mathrm{R}^{2}$ (Adjusted R Square) is 0.920 or (92\%). This shows that the Business Environment (X1), Availability of Capital (X2) and Marketing Strategy (X3) have an influence on Entrepreneurial Success (Y) while the remaining $8 \%$ is influenced or explained by other variables not included in this research model, namely member participation, cooperative management, cooperative management, and cooperative financial reports (Hanafiah, 2012).

\section{REFERENCES}

Bambang, Riyanto.2001. Dasar-dasar pembelajaran perusahaan. Edisi Keempat. Yogyakarta: BPFE.

Basu Swastha, DH dan Irawan. 1990. Manajemen Pemasaran Modern. Yogyakarta: Liberty.

Hanafiah. 2012. Faktor-faktor Keberhasilan Pengelolaan Koperasi Sekolah (Studi Pada Koperasi Keluarga Sejahtera SMPN 2 Rambah). Vol. 2, No. 1, Maret 2012

Wiratmo, Masykur. 2001. Pengantar Kewiraswastaan (Kerangka Dasar Memasuki Dunia Bisnis). Yogyakarta: BPFE-Yogyakarta.

Purwanti. 2012. Pengaruh Karakteristik Wirausaha, Modal Usaha, Strategi Pemasaran Terhadap Perkembangan UMKM di Desa Dayaan dan Kalilondo Salatiga. Among Makarti, Vol.5 No.9, Juli 2012

Setiaji. 2009. Pengaruh Partisipasi Anggota Dan Lingkungan Usaha Terhadap Keberhasilan Koperasi Pegawai Republik Indonesia (KPRI) Kapas Kecamatan Susukan Kabupaten Banjarnegara. Jejak, Vol. 2, No. 1, Maret 2009

Tjiptono, Fandy. 2008. Strategy pemasaran. Edisi 3, Andi: Yogyakarta 